\title{
INTEGRATION OF GIS TECHNOLOGY, REMOTE SENSING AND MULTIVARIATE ANALYSIS IN THE DELIMITATION OF PHYSIOGRAPHIC UNITS FOR PEDOLOGICAL MAPPING
}

\author{
M.R.Nanni ${ }^{1} \&$ H.O.Rocha ${ }^{2}$
}

KEYWORDS: Soil survey, cluster analysis, GIS, remote sensing.

NANNI, M.R.; ROCHA, H.O. (1997) Integration of GIS technology, remote sensing and multivariate analysis in the delimitation of physiographic units for pedological mapping. Bol.IG-USP. Sér.Cient., 28:129-143.

\section{ABSTRACT}

This study was based on an association of techniques and equipment that could lead to the delimitation of physiographic units not merely restricted to the photointerpreter's criteria. A data matrix was evaluated which was obtained from the crossing, by means of Geographic Information System (GIS), of a regular grid with cells $300 \times 300$ meters and a drainage base map of the study area and bands $3,4,5$ and 7 from TM-LANDSAT and a slope map generated in a GIS. The variables collected in each cell of the regular grid were: long, medium and short channels from the first to the seventh order, weighted slope and the grey levels (DNs) in bands, resulting in a matrix with 1167 individuals with 27 variables, whose data were subjected to cluster analysis. This analysis provided dendrograms which enabled the separation of groups of individuals represented by cells from the regular grid, aiming at creating pictograms to serve as "guides". These guides overlaid upon properly treated and handled orbital HRVSPOT images oriented the discrimination of physiographic units on the color monitor of the image processing system. Among the variables used, those referring to drainage network were best for cluster analysis of regular grid cells. The variables relief and grey levels of TM-LANDSAT image also presented satisfactory results with the methodology applied.

\section{RESUMO}

Este trabalho foi conduzido com o propósito de estabelecer-se um levantamento pedológico semidetalhado no Municipio de Ivatuba-PR, usando a associaçăo entre técnicas e equipamentos que pudessem levar a delimitação de unidades fisiográficas cujos limites e subdivisões não se restringissem apenas ao critério do fotointérprete. Para tanto, foi avaliada uma matriz de dados obtida através do cruzamento, por meio de um Sistema de Informaçס̃es Geográficas (SIG), entre uma grade regular com células de $300 \times 300$ metros e um mapa base de drenagem da área de estudos, bandas $3,4,5$ e 7 do TMLANDSAT e um mapa de declividades da área gerado em SIG. As variáveis coletadas dentro de cada célula da grade regular foram: canais longo, médio e curto das ordens $1^{z}$ a $7^{2}$, declividade ponderada e o nivel de cinza das bandas, resultando na produção de uma matriz com 1167 individuos com vinte e sete variáveis, cujos dados foram expostos à analise de agrupamentos. A análise propiciou a produçăo de dendrogramas que foram analisados, permitindo a representação pelas células da grade regular, com a

\footnotetext{
'Universidade Estadual de Maringá, Maringá, Paraná, Brasil.

${ }^{2}$ Universidade Federal do Paraná, Paraná, Brasil.
} 
finalidade de criação de pictogramas em que a separação de grupos de individuos servissem de "guias" que, sobrepostos às imagens orbitais HRV-SPOT devidamente tratadas e manipuladas, pudessem orientar a discriminação de unidades fisiográficas através da interpretaçâo destas sobre o monitor colorido do sistema SITIM. Foram delimitados 62 poligonos que configuraram a presença de nove unidades fisiográficas que geraram um mapa de solos semidetalhado do municipio. Em relaçâo à possibilidade de mapeamento das unidades fisiográficas sobre o monitor colorido, os resultados apresentados demonstraram que, através da utilização dos guias, tais unidades podem ser delimitadas com grande redução da subjetividade do fotointérprete. Os poligonos semelhantes, delimitados pela metodologia utilizada, apresentaram solos homogêneos dentro de sua classe taxonômica. Já os poligonos diferentes apresentaram solos com características diferenciadoras entre si.

\section{INTRODUCTION}

The main goal of soil surveying consists in the division of heterogeneous areas into homogeneous sections by means of classification parameters predefined by characteristics used for soil distinction at the map scale (Embrapa, 1984).

Subdivisions occur mainly in the first phase of soil surveying, in which aerial photographs and/or orbital images are normally interpreted, and areas with similar morphological and physiographic aspects are delimited by characteristics inherent to the images and intrinsic capacity of the photointerpreter.

Hilwig \& Karale (1973) established that the first step consists in doing a physiographic analysis to make the recognition of different types, forms and landscape units more feasible. This was initially introduced by Buring (1960) in his analysis of elements, later developed by Vink (1963) and Goosen (1968).

Research carried out during the last decades, related to the use of image photointerpretation for soil cartography, has revealed considerable concern regarding an author's subjectivity in mapping. Myers (1975) and Way (1978) state that soil mapping with aerial photographs needs subjective judgements. However, soil mapping at the surface also requires some subjectivity. The interpretation of photographs and/or orbital images depends on the photointerpreter's experience. It is thus expected that pedological surveying would have different results when done by different people.

Myers (1975) emphasizes the necessity of sharp delimitations among different soil classes. This is not always possible and some mistakes occur independently of how the mapping is done.

Bie \& Beckett (1973) state that mistakes in soil mapping may be very frequent. In their studies of a region in Cyprus four soil maps were compared. These maps were produced from a photointerpretation of the area by four cartographers who worked independently and without any restrictions. Results showed that the maps produced were considerably different among themselves. They concluded that the percentage of sharpness and degree of variability of soil properties within the map units were lower than those of the landscape as a whole.

Valério Filho (1984) states that the choice of such photointerpretation criteria as relief, drainage and photographic texture is considerably less liable to subjectivity by the photointerpreter in the individualization of representative physiographic soil units.

Within soil cartographic research there is a need to introduce and analyze elements that would help in the basic proceedings of photointerpretation and delimitation of physiographic units and thereby lessen the author's subjectivity. In this sense we will evaluate the possibility of establishing guide to help the 
photointerpreter in outlining physiographic units for soil mapping. Integration using GIS, remote sensing and multivariate analysis has thus been established in which a data matrix related to land drainage network, slope and gray scales of bands $3,4,5$ and 7 of a TMLANDSAT image was submitted to cluster analysis which made possible the building of pictograms to function as guides. These guides helped in the delimitation and individualization of physiographic units over a multi-spectral HRV-SPOT image. The choice of variables in the present study is due to the huge bibliography which refer separately or jointly to their use in soil studies (Rocha, 1993). Pictograms have been registered in different information plans of the Geographic Information System and introduced in the process of photointerpretation of orbital images.

\section{MATERIALS AND METHODS}

The area under analysis, representative of an agricultural and cattle raising sector, lies in the municipality of Ivatuba in the northwestern part of the state of Paraná, Brazil, or rather, in the Third Plateau or Plateau of Apucarana (Maack, 1981), limited by geographic coordenates latitude $23^{\circ} 30^{\circ}-23^{\circ} 45^{\prime} / \mathrm{S}$ and longitude $52^{\circ} 00^{\prime}-52^{\circ} 20^{\prime} / \mathrm{W}$. It has a total area of $93,599 \mathrm{~km}^{2}$ and an average altitude of $490 \mathrm{~m}$ (Paraná, 1982).

The region's climate lies between ropical and temperate. According to the Paraná climatic chart based on Koeppens, climate is Cfa with wet mesothermic subtropical climate, hot summers, less frequent frost than in other regions of the state of Paraná, average temperature between $18^{\circ} \mathrm{C}$ and $24^{\circ} \mathrm{C}$, and annual rainfall average $1,500 \mathrm{~mm}$ (Iapar, 1994).

The area lies on the Serra Geral Formation and belongs to the São Bento Group which covers in about $53 \%$ of the area of Paraná (Leinz \& Amaral, 1987). This formation, Early Cretaceous in age, is predominatly made up of successive layers of subhorizontal basalts, subordinate fine to silty sandstone and small rare intertrap siltstone-sandstone dikes. Besides basalt the area presents in lesser quantities a Cenozoic layer with colluvium, alluvium and colluvium-alluvium deposits. These deposits comprise river gravel, sub-recent modeling alluvion, terraced alluvion and present alluvion which correspond to deposits originally formed in alluvial plains, chiefly along the Ivai River. There is also the present formation of alluvion deposits in small floodplains near those of the Ivai River. These deposits are basically composed of homogeneous sand and sand-clay matter, of a grey colour and light grey to yellow grey, without any evident sedimentary structures (Gimenez Filho et al., 1981).

\section{Cartographic base}

The following basic cartographic documents were used:

a) Topographic maps, scale 1:50,000: Jussara sheet (SF22-Y-D-IV-1) and Ivatuba sheet (SF22-Y-D-IV-2), both made by the Directory of Geographic Service (DGS) in 1990;

b) topographic map, scale $1: 25,000,5$ meter equidistant terrace curves, made by the Environmental Institute of Paraná (IAP), limited by UTM coordenates $366-368 \mathrm{~km}$ and 7382 $7400 \mathrm{~km}$;

c) map of slope classes, scale 1:25,000, made by the SGI-INPE and produced by the Laboratory of Photointerpretation and Remote Sensing of the Federal University of Paraná (Nanni, 1995).

\section{Images}

Vertical panchromatic aerial photographs were used, approximate scale $1: 25,000$, taken in 1980. Orbital images 
of sensors TM-LANDSAT and HRVSPOT, with characteristics found in Table 1.

Table 1 - Characteristics of orbital images.

$\begin{array}{lcccc}\begin{array}{l}\text { Product } \\ \text { TM- }\end{array} & \text { Path* } & \begin{array}{c}\text { Row } \\ \text { (WSR) }\end{array} & \text { Bands } & \begin{array}{c}\text { Date of } \\ \text { passage }\end{array} \\ \begin{array}{l}\text { LANDSAT } \\ \text { (WN }\end{array} & 76-\mathrm{D} & 3,4,5,7 & 13 / 06 / 1991 \\ \begin{array}{l}\text { HRV- } \\ \text { SPOT }\end{array} & 705 & 397 & \begin{array}{l}\text { Sx1 } \\ \text { Sx2 } \\ \text { Sx3 }\end{array} & 23 / 08 / 1988 \\ & & & \end{array}$

*For SPOT scenes, reference system of SPOT grid (GRP)-INPE is called K (path)/J (row).

\section{Instruments}

SITIM/SGI, produced by the $\mathrm{Na}$ tional Institute of Spatial Research (INPE) was used as georeferenced data base and image processing system.

Pocket and table stereoscopes (Vasconcelos and Wild) were used for stereoscopic observation of aerial photographs.

\section{METHODOLOGY}

The association of two methodologies was applied in this research. The first is based on the visual interpretation of orbital images in digital format according to Valério Filho et al. (1981), Donzeli et al. (1983), and Vettorazzi (1988). The second is based on pictograms obtained by multivariate analysis as a guide superposed upon previously registered and conveniently treated images to help in the photointerpretation.

Work began by the production of a base map of land drainage conceived by the photointerpretation of vertical panchromatic aerial photographs. The surface land drainage was traced on overlays according to Strahler (1957), Lueder (1959) and Ray (1963). Overlays were placed on a land drainage map plotted by SGI on the same average scale as that of the aerial photographs. The map was redigitized for the composition of the base map.

A Digital Elevation Model (DEM) was produced (Felgueiras \& Erthal, 1988) which also originated a slope map with classes of plain relief, slightly undulated relief undulated relief and heavily undulated relief, according to intervals suggested by Embrapa (1984).

In the SGI a layer was produced consisting of a regular grid covering the area under analysis with cells $300 \mathrm{~m} \mathrm{x}$ $300 \mathrm{~m}$. For the scale $1: 50,000$ this size is equivalent to minimum area of land that could be mapped for a semi-detailed soil survey. This layer was then compared with TM 3,4,5 and 7 bands of a duly registered TM-LANDSAT image, the drainage land base map and the slope map produced by SGI. With regard to each band, the grey central levels of each cell composing the screen were taken from the TM-LANDSAT image. The pixel reader of SITIM-340 was applied to this end (Engespaço, 1989).

Information above the order of channels was placed on the land drainage map according to Horton (1945), who considers non-braided tributary channels as first-order channels. The link between two channels of the first order produces a second-order channel, and so on. Three classes of channel length were used (long, medium and short) since it is believed that each drainage channel of different order should influence in a different manner the respective portion in each cell. A short first-order channel, for example, will have a different influence on a cell if compared with a long first-order channel.

Medium lenght was chosen to represent size classes. From it a gauge was made in a scale comparable to that of the plotted drainage map for the counting of the channels in each cell accord- 
ing of their length and order. Values of each cell fed the data base.

From the slope map produced by SGI, weighted average slope was taken from within each cell, according to the following equation:

$\mathrm{DP}=\frac{(1.5 \% \times \mathrm{A} 1+5.5 \% \times \mathrm{A} 2-14 \% \times \mathrm{A} 3+32.5 \% \times \mathrm{A} 4)}{\sum \mathrm{A}}$

where: DP = is the weighted slope inside the cell; A1, A2, A3, A4 = area occupied by specific cell at each slope class; values $1.5 \%, 5.5 \%, 14 \%$ and $32.5 \%$ are the averages of intervals of slope class worked out by Embrapa (1984).

Cluster analysis was used to define homogeneous groups by cell linking as a function of their quantitative values.

Analysis of groupings consists of a variety of techniques and algorithms whose objective is to separate units or individuals in similar groups (Bussab et al. 1990).

According to Curi (1983) each individual belonging to a multivariate sample may be considered a point within a multidimensional Euclidian space when various measurements are undertaken in a single unit.

Data obtained from the drainage network analysis, weighted slope and grey scale values for each cell were tabulated and organized in a data base in the form of a matrix (Table 2) indicated by the expression $\mathrm{X}=\left(\mathrm{X}_{\mathrm{ij}}\right)$ whose dimensions are $\mathrm{n} \times \mathrm{p}$, where $\mathrm{n}$ indicates attributes and $\mathrm{p}$ indicates variables.

The organized matrix presented a total set of 1,167 attributes (cells) registered in 27 variables. Twenty-one are related to the number of long, medium and short channels of seven orders (1L, $2 \mathrm{~L}, 3 \mathrm{~L}, 4 \mathrm{~L}, 5 \mathrm{~L}$...) found in all the study area. So that original values might be transformed into adimensional values, the standardization of the above data was undertaken.

The application of a standardization function was necessary since a differentiation occurs among the dimension units. In their original form they may cause arbitrary effects which could jeopardize and affect the analysis. Through standarization, average is reduced to zero and standard deviation becomes a unit.

Average Euclidian distance was used as a similarity coefficient, where the square of the sum of differences among values is divided by the number of coordinates involved, or rather:

$\mathrm{d}(\mathrm{A}, \mathrm{B})=\left[\sum_{i=1}^{p}(x i(A)-x i(B))^{2} / p\right]^{1 / 2}$

where: $d(A, B)=$ average Euclidian distance between cells $\mathrm{A}$ and $\mathrm{B} ; \mathrm{p}=$ number of parameters (variable); $x i(A)$ $=$ value of parameter $\mathrm{i}$ for cell $\mathrm{A}$; xi(B) $=$ value of parameter $\mathrm{i}$ for cell $\mathrm{B}$.

Table 2. Section of data matrix used for cluster analysis.

$\begin{array}{lllllllllllllll}\text { CELL } & 1 & 1 & 1 & 2 & 2 & 2 & 3 & 3 & 3 & \text { B7 } & \text { B5 } & \text { B4 } & \text { B3 } & \text { DP } \\ & \text { L } & \text { M } & \text { S } & \text { L } & \text { M } & \text { S } & \text { L } & \text { M } & \text { S } & & & & & \% \\ 04-70 & 0 & 0 & 1 & 1 & 0 & 0 & 1 & 0 & 0 & 15 & 35 & 49 & 26 & 12,478 \\ 04-71 & 0 & 0 & 0 & 0 & 0 & 0 & 0 & 0 & 0 & 07 & 27 & 34 & 14 & 11,500 \\ 05-70 & 0 & 1 & 1 & 0 & 0 & 0 & 0 & 0 & 0 & 14 & 69 & 25 & 28 & 12,616 \\ 05-71 & 0 & 0 & 0 & 0 & 0 & 0 & 0 & 0 & 0 & 11 & 24 & 36 & 22 & 11,865 \\ 06-70 & 0 & 0 & 0 & 0 & 0 & 0 & 0 & 0 & 0 & 16 & 40 & 34 & 27 & 7,304\end{array}$

$\mathrm{L}=$ long; $\mathrm{M}=$ medium; $\mathrm{S}=$ short; $\mathrm{B} 7,5,4,3$ = levels of grey bands of TM-LANDSAT. 
The average Linkage method was chosen for grouping. The use of this method was due to the possibility of the construction of hierarchical and agglomerate groups where, through the successive fusion of $n$ objects, $n-1, n$ $2, \ldots$, groups are obtained until all the objects are linked in a single group.

This grouping method will make possible the formation of phenograms or dendrograms (hierarchical classification trees) which make the similarity between the groups of elements analyzed more easily visible.

For cluster analysis, the file with the data matrix was transferred to the CLUSTER $^{\text {TM }}$ program where standardization of data, grouping, construction and impression of dendrogram were executed. Due to the limitations of the software, the study area had to be divided into eight parts with approximately 145 cells each and its dendrograms analyzed to discriminate cell groups.

Sets of cells formed by the visual separation of dendrograms were identified by one colour in SGI and stored in different layers. A different class was thus registered in each set forming a pictogram (Fig. 1).

One by one the information layers produced within SGI were overlaid onto the coloured and auxiliary compositions of the HRV-SPOT image. With each overlay the dynamic processes of the landscape with the existing soils were registered by physiological analysis according to Goosen's criteria (1968) together with those adapted by Donzeli et al. (1983) for MSS/RBV-LANDSAT images. Through the relationship soillandscape and with the help of the guide layer information, delimiting outlines were established among the landscape units on the images. Thus, these units were obtained by the association of analysis and visual interpretation of orbital images with the overlying cluster analysis results. These serve as guides to determine their limits.

Each image on the monitor was overlaid by the drainage network to obtain a more enhanced view of the scene and to make photointerpretation easier. With the delimitation of all the polygons containing physiographical units, a map was printed on a scale of $1: 25,000$, with drainage network and road complex of the municipatily so that field work could be continued.

During field work the normal methodology of Embrapa (1996) was employed in the soil survey. A plan was elaborated with the aim of passing through all the units and undertake transects in each one that would cover all the slopes.

Thus the systematic phase of prospection and observation of the soil's morphological characteristics in various geomorphic surfaces began. The aim was to prepare preliminary entries which were gradually modified as work progressed. Observations were made along the transects, previously prepared ditch or base profiles analyzed and samples collected in specific spots by boring. Morphological descriptions of the profiles were made according to criteria of Lemos \& Santos (1984).

All preparation, treatment, and analysis of samples sent to the laboratory followed the methodology for soil surveying of Embrapa (1979). Physical, chemical, and minerological analyses were undertaken, such as a) grain-size analysis; b) texture classification; c) soil density (sd); d) density of particles (dp); e) total porosity of soil; f) $\mathrm{pH}$ in water and in $1 \mathrm{~N} \mathrm{KCl}$; g) delta $\mathrm{pH}$; h) exchangeable $\mathrm{Ca}^{++}+\mathrm{Mg}^{++}$; i) exchangeable $\mathrm{K}^{+}$and $\mathrm{Na}^{+}$; j) sum of bases; $\mathrm{k}$ ) exchangeable aluminium $\mathrm{Al}^{+++}$; 1) Hydrogen + exchangeable aluminium $\left(\mathrm{H}^{+}+\right.$ $\mathrm{Al}^{+++}$; m) capacity of cation exchange $(\mathrm{CCC}) ; \mathrm{n})$ percentage of base saturation 


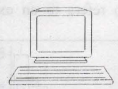

IMAGEM TM-LANDSAT REGISTRADA

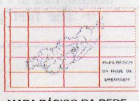

MAPA BÁSICO DA REDE OE DRENAGEM

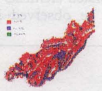

MAPA DE DECLIVIDADES

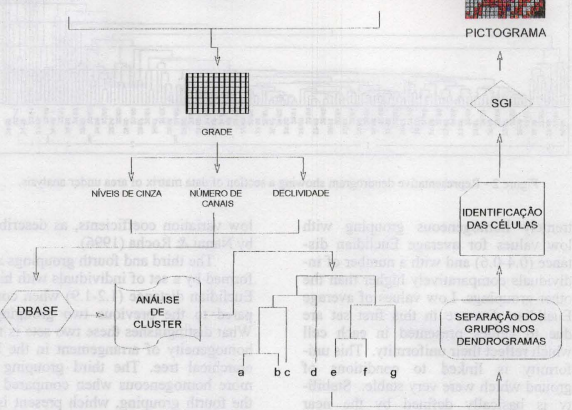

Figure 1-Fluxogram of process to obtain pictograms.

(V); o) percentage of saturation by aluminium; p) absorbable phosphorus; q) organic carbon $(\mathrm{C}) ; \mathrm{r}$ ) organic matter; s) clay activity $(\mathrm{T})$; t) $\mathrm{Fe}_{2} \mathrm{O}_{3}$.

Minerals species were qualitatively identified in the coarsest soil size fractions using a $50 \mathrm{X}$ binocular microscope. Quantities of species were not determined as the aim of the analysis was to compare different soils and to correlate spot samples by means of the mineralogy of the sand fraction.

\section{RESULTS AND DISCUSSION}

The application of cluster analysis and production of dendrograms as a process for the compartmentalization of cells to form a pictogram proved to be very satisfactory. Use of established variables makes it possible to separate or to group cells of a regular grid established for a specific area. This fact was also observed by Rocha (1993).

Because of software limitations in the cluster analysis, the area was separated into eight sections to produce eight dendrograms. In the following discussion the dendrogram of one such section of the area under analysis will be presented.

The separation of five principal 
groups and two isolated elements (Cells $23: 43$ and $24: 38$ ) be observed in the dendrogram in Figure 2.

The first group refers to an ex-

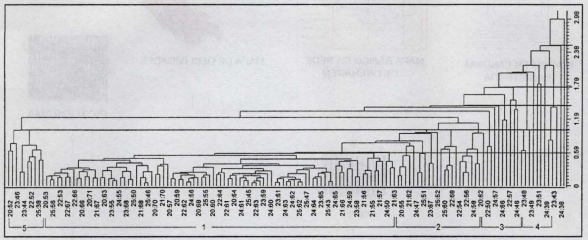

Figure 2 - Representative dendrogram showing a section of data matrix of area under analysis.

tremely homogeneous grouping with low values for average Euclidian distance (0.4-0.6) and with a number of individuals comparatively higher than the other groupings. Low values of average Euclidian distance in this first set are due to values presented in each cell which reflect their uniformity. This uniformity is linked to conditions of ground which were very stable. Stability is basically defined by the near absence of drainage channels, plain slope, and small variation of grey level values. Soils present in such separated areas in this grouping are represented by typic eutrorthox whose physical and chemical characteristics were very stable (Nanni \& Rocha, 1996).

The second grouping presents intermediate values for Euclidian distance (0.6-1.0) with a greater heterogeneity than that of the first grouping. In these areas latosolic soils were identified with interlayers towards Rhodic Paleudalf whose characteristics begin to show some change. This fact did not allow such great uniformity as in the first grouping. Within the unit, differentiating characteristics presented relatively low variation coefficients, as described by Nanni \& Rocha (1996).

The third and fourth groupings are formed by a set of individuals with high Euclidian distance (1.2-1.9) when compared to the previous two groupings. What distinguishes these two sets is the homogeneity of arrangement in the hierarchical tree. The third grouping is more homogeneous when compared to the fourth grouping, which present isolated individuals and average Euclidian distance higher than 1.2. Since each dendrogram refers to a section of the studied area, it may contain individuals which represent soils present in this section.

The fifth grouping has a Euclidian distance relatively close to the second and third groupings (1.0-1.2) but totally separated from the other groups (in the left of the dendrogram). Soils in areas separated by this grouping represent hydromorphic soils whose characteristics are very similar among themselves. This may be observed by the low values of Euclidian distance of cells that comprise this group. On the other hand, they are easily distinguished from the rest since 
their characteristics are very distinct.

As far as it was possible, cuts were established for all dendrograms at comparable levels, or rather, within variations normally occurring in each tree. Cuts for chosen groupings did not vary in values of average Euclidian distance, which resulted in the formation of clearly distinct groups. According to Vettorazzi (1988), cuts made in the dendrogram should be made at points which satisfy the requirements of the work.

For all dendrograms analyzed, the same distinct hierarchical groups were observed in spite of the fact that in some cases their distribution on the phenogram was variable. In almost all the phenograms small groupings were separated within the principal sets (chiefly the third and fifth groups). These small groupings were similar to one or other principal grouping within the hierarchical tree. They are thus considered as variations of the principal groupings although separated from the rest. In Table 3 the principal groupings are presented as defined in the dendrograms for each of the eight sections used in this analysis.

As has been established in section 2 , the other sections have different den

Table 3 - Number of tells and groups separated by dendrogram analysis in the eight sections of the study area.

$\begin{array}{lcc}\text { SECTION } & \text { NUMBER OF CELLS* } & \text { NUMBER OF GROUPS** } \\ 01 & 166 & 05 \\ 02 & 145 & 05 \\ 03 & 146 & 05 \\ 04 & 138 & 04 \\ 05 & 147 & 04 \\ 06 & 156 & 04 \\ 07 & 144 & 04 \\ 08 & 126 & 06\end{array}$

* Variation in number of cells per section is the result of the area's irregular shape. Organization of the sections with the same number of cells without the disruption in the sequence of the regular grid is thus made impossible.

** Number refers to groupings obtained by the cuts in the hierarchical tree according to established aims.

drograms which made possible the separation of groups of individuals which, duly identified and labelled by GIS, led to the formation of the pictogram of the area under analysis (Fig. 3), as obtained by Rocha (1993).

\section{Interpretation of digital images and delimitation of physiographic units.}

The use of orbital images made possible the compartmentalization of homogeneous areas of the land and established itself as an important tool in soil studies (Westin, 1973; Myers, 1983; Westin \& Frazze, 1976; Valério
Filho et al., 1981; Imhoff et al., 1982; Donzeli et al., 1983; Agbu et al., 1990; Gastellu-Etchegorry et al., 1990; Biswas \& Singh, 1991; Rocha, 1993).

The best scene was that obtained by the interposition of bands SX2 ( 0.61 $0.68 \mu \mathrm{m}), \mathrm{SX} 3(0.79-0.89 \mu \mathrm{m})$, SX1 $(0.50-0.59 \mu \mathrm{m})$ of the HRV-SPOT sensor in channels $R, G$, and $B$, respectively, filtered and linearly contrasted by histogram manipulation (Fig. 4).

When used alone, band SX3 (Fig.

5) presented the best results. The visualization of objects was clearer in 


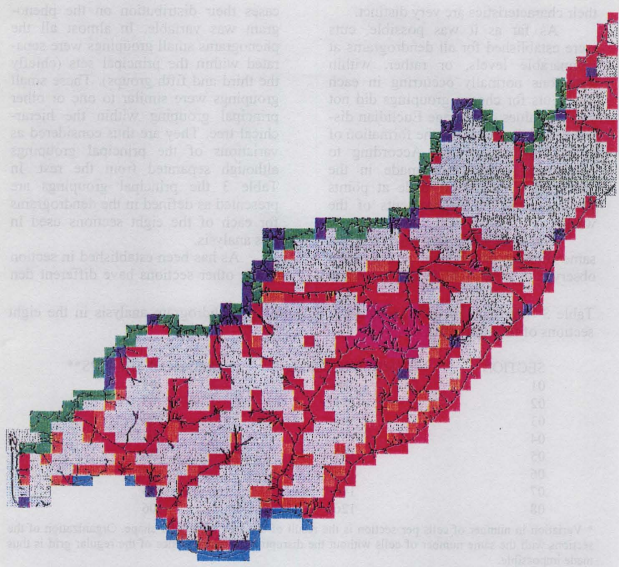

Figure 3 - Pictogram of area formed by analysis of groupings.

comparison to other bands which produced a darker tone, even after being linearly contrasted. By the use of guide polygons, the discrimination of physiographic units becomes feasible even through the use of only one band. Therefore, the use of at least two bands, as has been suggested by Santos et al. (1988), is not necessary.

The scene obtained in the winter of 1988 and therefore at a low angle of solar elevation was extremely useful with regard to conditions of local relief. This was due to the shadowing effect which was already remarked on by Valerio Filho et al. (1981) and Vettorazzi (1988). The characterization of relief as crests, flat surfaces, depressions and river beds was relatively easy and made feasible by intense agricultural activity and absence of forests. Besides, the use of filters together with the superposition of the drainage network on the photointerpreted scene and the observation of photographic texture made it possible, for certain sections of the area, to visualize better the degree of topographic dissection. Physiographic analysis was 


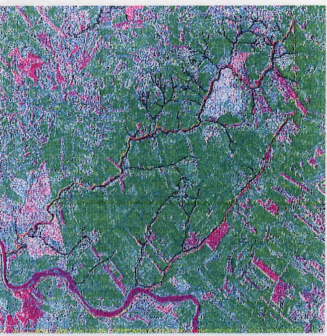

Figure 4 - HRV-SPOT image of area under analysis in colored composition SX2(R), SX3(G) and $\mathrm{SXI}(\mathrm{B})$.

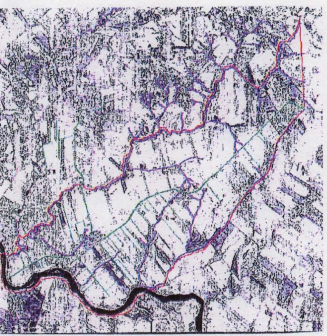

Figure 5 - Band $\mathrm{SX}_{3}$ of HRV-SPOT image overlain by drainage wed (blue), perimeter of area (red) and roads (green).

thus optimized.

Another very useful element in the characterization of the shape of the relief was the system of terraces executed in agricultural areas for the conservation of soil. It was possible to observe small alterations in the area's morphology with a certain sharpness, by means of the sinuosity of these curves.

The processes of separation of physiographic units based on the methodology adopted by Donzeli et al. (1983) showed once more their great capacity in the delimitation of physiographic aspects by means of the characteristics of the drainage network, relief, and photographic image associated with the guides obtained by the method itulized in the present paper.

In the case of mapping the units of the area under analysis, the sum of all the information obtained by interpretation of digital images and the use of the guides contributed significantly to their better characterization. Hence, the adopted procedure proved satisfactory for the compartmentalization of the land within the preestablished aims, that is, to subdivide the land into homogeneous areas with a sharp reduction in the subjectivity of the photointerpreter. This is due to the fact that such subdivisions followed conditions which, in this case, consisted of the guides obtained by cluster analysis. This fact has also been acknowledge by Rocha (1993). As Vettorazzi (1988) has already shown, an area of land represented by a polygon may or may not be separated from another by the similarity between individuals which were grouped for the formation of this unit and not by the subjectivity of the author's interpretation.

The guides formed by the pictogram and superposed on the images (Fig. 6) assured a great degree of reliability in outlining dividing lines between units which, in some places and because of conditions inherent to the images, were not clearly defined. De- 


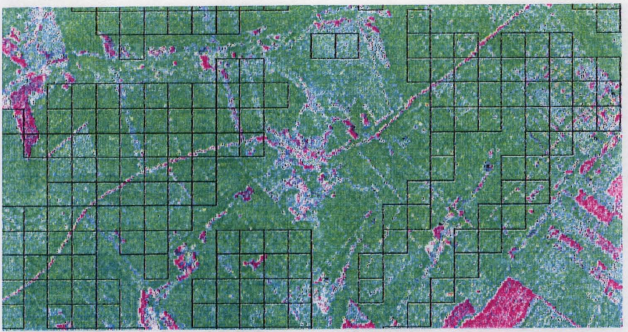

Figure 6 - Section of HRV-SPOT image with superposed guide for individualization of physiographic units.

spite various treatments for bettering visual quality, the chosen image presented conditions in some areas which did not allow characterization of physiographic units. This was due to the classical methodology used. Such units were only separated through indications of the guides. After field work and analysis it was verified that areas previously separated were really different, even though no significant difference had been detected by visual analysis. In other words, areas that probably could be separated by visual analysis of the image, were maintained within a single unit since the polygon guide overlying the image kept them united. Later studies proved the veracity of this procedure.

Field work established classes of soil which, within the adopted scale and the categorical level used in the classification system, presented low coefficients of correlation for almost all the physical and chemical properties (Nanni \& Rocha, 1996).

It is important to note the great contribution that guides formed by pictograms gave in visual analysis of orbital images. They may separate individuals which are not visually distinct and they may maintain together units which are usually separated due to differentiations in colour and contrast.

With regard to the limits of polygons delimited by guides, observations during field work have established their coincidence with laboratory data in almost all areas. The greatest difficulty was in the comprehending band of some physiographic units, especially those near rivers. Due to the size of the cell $(300 \times 300 \mathrm{~m})$ certain limits were defined within the width of this band. After some field observations it was verified that in some cases limits between units varied with regard to their width.

After interpretative analysis of the image and the definition of dividing lines between polygons, physiographic units were established from which a map was produced and checked in the field. Each polygon was identified and labelled to determine its area. In all, 62 
polygons were delimited which represented the studied area.

Five consociations and four associations of soil were identified belonging to 13 taxonomical units according to the classification suggested by the $\mathrm{Na}$ tional Service of Surveying and Soil Conservation. The identified and described soils were: typic Eutrothox and typic Haplorthox (LRe, LRd), typic Haplorthox (LEd), Rhodic Paleudalf (TRe), Oxic Argiudoll (TRelat); shallow Rhodic Paleudalf (TRepp), typic Eutrochrept (Ce), typic Hapludoll (Re), typic Udorthent, Gleyed Cambisols and eutrophic Alluvial Soils. Soils present in the area are basically eutrophic with relatively high values of nutrients. According to geomorphic conditions, the deepest soils are Latosols and Rhodic Paleudalf soils that lie in areas with an approximately $5 \%$ slope. In areas with greater declivities shallower soils as found (Litholic, Cambisols and shallow Rhodic Paleudalf soils). Close to the Ivai and Bandeirantes Divers, alluvial and hydromorphic soils were found associated or not with other units (Cambisols). Because of their geological conditioning, the great majority of soils are clayey and more clayey, with a great capacity for water retention and greater than $50 \%$ total porosity. Physical and chemical characteristics favor intense agricultural activity with a high capacity of producing short-cycle and nutrientdemanding cultures (Nanni \& Rocha, 1996).

\section{CONCLUSIONS}

The use of a pictogram as a guide for the separation and delimitation of physiographic units on orbital images has proved satisfactory for the established aims and considerably reduces the subjectivity of the photointerpreter.

Pictograms were mounted with great efficiency from cell groupings obtained by cluster analysis.

The use of cluster analysis made the separation of polygon guides possible at safe levels, linked to numerical values, represented by similarity coefficients and the groupings formed by individuals identified within the dendrogram.

Soils described by field surveying confirmed the homogeneity of the units defined by this methodology.

\section{REFERENCES}

AGBU, P.A.; FEHRENBACHER, D.; JANSEN, I.J. (1990) Soil property relationships with SPOT satellite digital data in east central Illinois. Soil Science Society of American Journal Madison, v.54, p.807-81.

BIE, S.W.; BECKETT, P.H.T. (1973) Comparison of four independent soil surveys by air-photo interpretation, Paphos area (Cyprus). Photogrammetria. Amsterdam, v.29, p.189-202, 1973.

BISWAS, R.R.; SINGH, C.P. (1991) Capability of TM data form evaluation of soil an land resources in the Malwa Plateau (Chambal and Mahi catchment) in Madhya Pradesh, India. International Journal of Remote Sensing, Hants, v.12, n.9, p.1905-1913.

BURING, P. (1960) The aplications of aerial photographs in soil surveys. In: Manual of photographic interpretation. Washington, American Society of Photogrammetry. p.633-666.

BUSSAB, W.O.; MIAZAKI, E.S.; ANDRADE, D.F. (1990) Introdução à análise de agrupamentos. In: SIMPÓSIO NACIONAL DE PROBABILIDADE ESTATÍSTICA 9., São Paulo, 1990. Publicação Avulsa. São Paulo, Associação Brasileira de Estatística. 105 p.

CURI, P.R. (1983) Análise de agrupa- 
mentos: métodos sequenciais, aglomerativos e hierárquicos. Ciência e Cultura, v.35, n.10, p.1416-1429.

DONZELI, P.L.; VALERIO FILHO, M.; NOGUEIRA, F.P.; PEREZ FILHO, A.; KOFFLER, N.F. (1983) Imagens orbitais e de radar na definição de padrões fisiográficos aplicados a solos. Revista Brasileira de Ciência do Solo, Campinas, v. 7, p. 89-94.

EMBRAPA. SNLCS. (1984) Levantamento de reconhecimento dos solos do Estado do Paraná. Curitiba, 1984. Boletim Técnico. Embrapa, n.57.

EMBRAPA. SNLCS. (1979) Manual de métodos de análise de solo. Rio de Janeiro, EMBRAPA.

EMBRAPA. SNLCS. (1996) Normas e critérios para levantamento pedológicos. Rio de Janeiro, EMBRAPA. 94 p.

ENGESPAÇO. (1989) Manual do usuário - SITIM 340/SGI. São José dos Campos, INPE.

FELGUEIRAS, C.A.; ERTHAL, G.J. Aplicações de modelos numéricos de elevação e integração com imagens digitais. In: SIMPÓSIO BRASILEIRO DE SENSORIAMENTO REMOTO, 5., Natal, 1988. Anais. São José dos Campos, INPE. p.485490.

GASTELLU-ETCHEGORRY, J.P.; MOHR, H.V.M.; HANDAYA, A.; SURJANTO, W.J. (1990) An evaluation of SPOT capability for mapping the geology and soils of Central Java. International Journal of Remote Sensing, v.11, n.4, p. $685-702$.

GIMENEZ FILHO, A.; PIRES NETO, A.G.; RICCOMINI, C. (1981) Mapeamento geológico do bloco SF22-T (ACS-73). São Paulo, Instituto de Pesquisas Tecnológicas. $69 \mathrm{p}$. (Relatório n. 14845).

GOOSEN, D. (1968). Interpretacion de fotos aereas y su importancia en levantamiento de suelos. Roma, Organizaciones de las Naciones Unidas para la Agricultura y Alimentacion. (Boletin sobre suelos, n.6).

HILWIG, F.W.; KARALE, R.L. (1973). Physiographic systems and elements of photo-interpretation as applied to soil survey in Ganges Plain. Indian Society of Soil Science Journal, v. 21, n. 2, p. $205-212$.

HORTON, R.E. (1945) Erosional development of streams and their drainage basins: hidrophysical approach to quantitative morphology. Geological Society of American Bulletin, v.56, p.275-370.

IAPAR.(1994) Cartas climáticas básicas do Estado do Paraná. Londrina, IAPAR. 41 p.

IMHOFF, M.L.; PETERSEN, G.W.; SYKES, S.G.; IRONS, J.R. (1982) Digital overlay of cartographic information on Landsat MSS data for soil surveys. Photogrammetric Engineering and Remote Sensing, v. 48, n. 8, p. $1337-1342$.

LEINZ, V.; AMARAL, S.E. (1987) Geologia Geral. São Paulo, Ed. Nacional. 397p.

LEMOS, R.C.; SANTOS, R.D. (1984) Manual de descrição e coleta de solo no campo. Campinas, SNLCS/ SBCS, 37p.

LUEDER, D.R. (1959) Aerial photographic interpretation: principles and applications. New York, McGraw-Hill. 462p.

MAACK, R. (1981) Geografia física do estado do Paraná. Rio de Jáneiro, José Olympio. 450p.

MYERS, V.I. (1975) Crops and soils. In: Manual of remote sensing. Fall Church, Americam Society of Photogrammetry. p.1715-1807.

MYERS, V.I. (1983) Remote sensing applications in agriculture. In: Manual of remote sensing. 2. ed. Fall Church, American Society of 
Photogrammetry. p.2119-2136.

NANNI, M.R. (1995) Delimitação de unidades fisiográficas para estudo de solos utilizando análise multivariada e técnicas de sensoriamento remoto. Curitiba, 196 p. (Dissertação - Mestrado) Setor de Ciências Agrárias - UFPR.

NANNI, M.R., ROCHA, H.O. (1996) Levantamento pedológico semidetalhado em porção noroeste do Estado do Paraná. In: CONGRESSO LATINO AMERICANO DE CIÊNCIA DO SOLO, 13., Águas de Lindóia, 1996. SP). Resumos Expandidos. Campinas, SBCS. (CD-ROM).

PARANA. Secretaria de Estado do Planejamento. Departamento de Estatística. Estatisticas Municipais. Ivatuba. 1982.

ROCHA, H.O. (1993) Integração de dados através da análise de agrupamentos $e$ interpretação de imagens orbitais para levantamento de solos. Curitiba, 106p. Tese (Professor Titular) - Setor de Ciências Agrárias - UFPR.

RAY, R.G. (1963) Fotografias aéreas na interpretação e mapeamento geológico. São Paulo, Instituto de Geografia e Geologia. 162 p.

SANTOS, M.J.; DA SILVA, A.F.; DE QUEIROZ, J.E.R. (1988) Comportamento espectral de solos a partir da análise de dados do TM/ LANDSAT - 5. In: SIMPÓSIO BRASILEIRO DE SENSORIAMENTO REMOTO 5, Natal, 1988. Anais. São José dos Campos, INPE. v. 1, p.898-902.

STRAHLER, A.N. (1957) Quantitative analysis of watershed geomor- phology. New Haven, Transamerican Geophysics University. v.38, p.913-920.

VALERIO FILHO, M. (1984) Parâmetros da drenagem e do relevo na caracterização de solos e suas relações fotointerpretativas em imagens de pequena escala. Piracicaba, 141 p. (Tese - Doutorado) ESALQ, USP.

VALÉRIO FILHO, M.; EPIPHANIO, J.C.N.; FORMAGGIO, A.R. (1981) Metodologia de interpretação de dados de sensoriamento remoto $\mathrm{e}$ aplicaçōes em pedologia. São José dos Campos, INPE/CNPQ. 52 p.

VETTORAZZI, C.A. (1988) Interpretação de imagens TM/Landsat-5, em duas escalas, na caracterização fisiográfica para mapeamento de solos. Piracicaba, $184 \mathrm{p}$. (Tese - Doutorado) - ESALQ-USP.

VINK, A.P.A. (1963) Fotografias aéreas y las ciencias del suelo. Paris, UNESCO.

WAY, D.S. (1978) Terrain analysis. Stroudsburg, Hutchinson \& Ross. $438 p$.

WESTIN, F.C.; FRAZEE, C.J. (1976) Landsat data, its use in a soil Survey program. Soil Science Society of American Journal, v.40, p.81-89.

WESTIN, F.C. (1973) ERTS-1 MSS imagery: its use in delineating soil associations and as a base map for publishing soil informations. In: EARTH RESOURCES TECHNOLOGY SATELLITE SYMPOSIUM, 3., Washington, 1973. Proccedings. Washington, NASA. v.1, p.183-204.

M.R.Nanni - Universidade Estadual de Maringá, Av. Colombo, 5790, CEP 87020-900, Maringá, PR, Brasil. 